\title{
Nomenclatural notes about the names in Amaranthaceae published by Roberto de Visiani
}

\section{Duilio lamonico ${ }^{1, *} \&$ Moreno Clementi $^{2}$}

\author{
Keywords: Amaranthaceae \\ s.str., Amaranthus L., Atriplex \\ L., Chenopodiaceae s. str., \\ Chenopodium L., lectotypification, \\ new synonymy, nomen nudum. \\ Ključne besede: Amaranthaceae \\ s. str., Amaranthus L., Atriplex \\ L., Chenopodiaceae s. str., \\ Chenopodium L., lektotipizacija, \\ novi sinonimi, nomen nudum.
}

Received: 14.4 .2015

Revision received: 25. 8. 2015

Accepted: 1. 9. 2015

\begin{abstract}
The names in Amaranthaceae published by R. de Visiani are investigated. Amaranthus gangeticus var. cuspidatus is a nomen nudum and thus invalid according to Art. 38.1a of the ICN. Amaranthus hierichuntinus, Atriplex patula var. hastifolia, and Chenopodium album var. oblongum are lectotypified, respectively, on a specimen preserved at PAD, and illustrations by Scopoli and Vahl. We here propose to synonymyze the three names (new synonymies) respectively with Amaranthus graecizans subsp. graecizans, Atriplex patula subsp. patula, and the type subspecies of $C$. album. For nomenclatural purposes, also the name $C$. lanceolatum Willd. (heterotypic synonym of $C$. album subsp. album) is investigated and lectotypified, on a specimen preserved at B.

\section{Izvleček}

Pregledali smo imena vrst iz družine Amaranthaceae, ki jih je objavil R. de Visiani. Amaranthus gangeticus var. cuspidatus je nomen nudum in je zato objavljeno ime neveljavno v skladu z Art. 38.1a Kodeksa nomenklature (ICN). Imenom Amaranthus hierichuntinus, Atriplex patula var. hastifolia in Chenopodium album var. oblongum smo določili lektotipe na podlagi primerkov, shranjenih v herbariju PAD in ilustracij, ki sta jih naredila Scopoli in Vahl. Predlagamo, da tri imena obravnavamo kot sinonime: Amaranthus graecizans subsp. graecizans, Atriplex patula subsp. patula in tip podvrste $C$. album. Zaradi nomenklaturnih razlogov smo preučili ime C. lanceolatum Willd. (heterotipski sinonim C. album subsp. album) in določili lektotip na podlagi primerka iz herbarija B.
\end{abstract}




\section{Introduction}

As part of ongoing researches on the taxonomy of Amaranthaceae in several projects, including the new edition of the Italian Flora (editor, Prof. S. Pignatti), the "Italian Loci Classici Census" initiative (see Domina et al. 2012, Peruzzi et al. 2015), the Euro+Med PlantBase, the Compendium Programme CAB International (by D. Iamonico, see e.g., Iamonico 2010, 2011, 2012a, 2013a, 2013b, 2014a, 2014b, 2014c, 2014d, 2015a, 2015b, Iamonico \& Das 2014, Iamonico \& Jarvis 2012, Iamonico \& Kadereit 2012, Iamonico \& Somlyay 2014, Iamonico \& Sukhorukov 2014, Iamonico \& Sánchez del Pino 2014, 2015, Sánchez del Pino \& Iamonico 2015, Sukhorukov et al. 2014), and on the nomenclature of the names published by R. de Visiani (by M. Clementi, see e.g. Clementi et al. 2014, 2015a, 2015b), we here present a joined contribution concerning the four names belonging to Amaranthaceae Juss. s.lat. (circumscription according to APGIII 2009) that were published by R. de Visiani.

\section{Materials and methods}

The work is based on an extensive analysis of literature and examination of the specimens preserved in the herbaria B, FI, G-DC, HFLA, LINN, NAP, RO, PAD and W (acronyms according to Thiers 2015 [continuously updated]). The articles cited through the text refer to the Melbourne Code (ICN, McNeill et al. 2012).

\section{Results and discussion}

\section{Amaranthus gangeticus var. cuspidatus}

Visiani (1842a: 54) proposed the taxon cuspidatus at the varietal rank, under Amaranthus gangeticus, associating with it the abbreviations "ann." (= "annua. Pianta erbacea annuale", i.e. "annual herbaceous plant"), and "s.d." (= "sub diu. Pianta che vive all'aperto", i.e. "plant living in the open") (see Visiani 1842a: 49). Lacking a description or diagnosis, this name is nudum, and, consequently, it is invalid according to Art. 38.1a. No specimens bearing labels referring to this variety were found in Visiani's collections, so it was not possible to elucidate his concept of this taxon.

\section{Amaranthus hierichuntinus}

Visiani's protologue (Visiani 1858: 139) consits of a detailed description, the provenance ("Hab. in herbidis circa Hierico", where "Hierico" is the city of Jericho, in
Israel/Palestine), and a diagnosis comparing it to $\mathrm{Am}$. polygonoides as treated in Willdenow (1790: 11), which should differ from $A$. hierichuntinus for having "utriculis [...] certe indehiscentis, flores monoici, calyx faemineus 5-fidus, utriculus calyce inclusus". The fact that this plant originates from the Middle East and is not from the western Balkans, the main area of study of Visiani's, might seem unusual. Although we were unable to retreive any information on the precise source of this material either in Visiani's published corpus or in his unpublished material, it must be noted that none the taxa presented in Visiani (1858a) were in fact collected by himself or his Dalmatian collaborators, but were instead all plants cultivated at the Botanical Garden of Padua, of which he was the director. Indeed, we also find in that work taxa that originate from the Americas (Tecoma, Dictyanthus) and tropical regions (Phyllanthes, Begonia). Referring to this taxon, there is one herbarium sheet preserved in PAD bearing two specimens, of which one is composed of two individuals (PAD-H0044649, mounted together on the top-left of the sheet), that were collected in June-July 1857. It must be acknowledged that, given the context, it is highly unlikely that this particular specimen originates from the locus classicus, as it was almost certainly cultivated in Padua from seeds that he received, as is the case with the other plants presented in that work (a fact that bears no nomenclatural relevance). The other specimen on the sheet (PAD-H0044650, on the bottom-right) is composed of three individual plants, and is associated to a label including the annotation "Amaranthus hierichuntinus Vis.", without a date or locality of collection. Since we cannot be sure whether or not PAD-H0044650 is part of the original material, we avoid it a possible choice for a lectotype. The two plants on the top-left are instead certainly part of the original material, and almost certainly part of the same gathering. This specimen matches the protologue, and is here designated as the lectotype of the name Amaranthus bierichuntinus. Concerning the identity of $A$. hierichuntinus, the lectotype shows the following characteristics: plants annual with stem erect or ascending, branched, glabrous, brownish; leaves lanceolate, the lower ones $1.0-2.4 \times 5.7-8.8 \mathrm{~mm}$ (ratio length/width 3.1-4.7), the middle 3.4-5.7 $\times 14.1-17.6 \mathrm{~mm}$ (ratio length/width $3.4-3.7$ ), the upper 1.0-1.7 $\times 3.7-9.9 \mathrm{~mm}$ (ratio length/ width 3.3-4.1), all petioled, glabrous with margins entire, base cuneate, and apex obtuse-mucronate; synflorescence arranged in axyllary glomerules, brownish; floral bracts 2 , as long as the perianth; pistillate flowers with 3 tepals acute, shortly pointed; stigmas 3 ; fruit brownish subglobose, dehiscent, longer than the perianth; seed lenticular, dark, smooth. This morphological structure 
perfectly matches $A$. graecizans L. subsp. graecizans, according to the current concept (see e.g., Costea 2003, Iamonico 2015a). We here propose the synonymization of the two names (new synonymy).

\section{Atriplex patula L. var. integrifolia, Atriplex patula L. var. hastifolia}

Visiani (1842b: 237) had a broad concept of Atriplex patula L., recognizing three varieties: $\alpha$. integrifolia Vis., $\beta$. hastifolia Vis. (a correction from the original "hastaefolia" - see art. 60.8), and $\gamma$. triangularis Willd. He distinguished these three varieties on the basis of the shape of the leaves: "foliis indivisis, basi attenuatis" (var. integrifolia), "foliis hastato-lanceolati, basi attenuatis" (var. hastifolia), and "foliis triangularis basi truncatis ..." (var. triangularis).

Visiani consistently used the letter $\alpha$ to indicate the nominal variety (see for instance his treatment of Suaeda maritima in Visiani 1842b: 243), In the case of $A$. patula var. integrifolia, this is explicitated with the words "species Linnaeana ea est, quam sub var. $\alpha$ proposui" (i.e. "the Linnaean species is that which I proposed under var. $\alpha$ "). It is therefore an invalid name, not complying with the provisions of Art. 26.2.

Concerning the var. hastifolia, two illustrations were listed in the protologue from Oeder et al. (1761-1883, "Icon. Fl. dan. T. 1285", image available at http://plantillustrations.org/illustration.php?id_illustration=109214) and Scopoli (1787, "Scop. delic. Insubr. Tab. VII"), which are part of the original material. Only one specimen was found in Visiani's collections in PAD (PAD-HD02188), bearing a label including the original annotation by $\mathrm{Vi}$ siani: "Atriplex patula $\beta$. hastaefolia In cultis insulae Lusin" (island of Lošinj, Croatia). Unfortunately, the date of collection is missing, and although we do know from a survey of Visiani's collections that most of his plants from the island of Lošinj were collected precisely in 1842 , we were not able to prove that this is the case also for this specimen. Since the doubts concerning the date, we avoid it for the purpose of lectotypification. Fortunately, the two images cited in the protologue are eligible as lectotypes, matching the diagnosis. As Scopoli's illustration also displays the bract-like cover at fruiting stage, whose characteristics have high taxonomic value in Atriplex (see e.g., Castroviejo 1990, Akeroyd 1993, Sukhorukov, 2006), we prefer to designate the image in Deliciae Flora et Fauna Insubricae as the lectotype for the name Atriplex patula var. hastifolia. According to the current concept (see e.g., Iamonico 2012b, Sukhorukov 2014), Visiani's variety shows features that completely overlap those of the nominal variety.

\section{Chenopodium album $\mathrm{L}$. var. oblongum}

The variety oblongum was described by Visiani (1842b: 240) to distinguish forms of Ch. album with lanceolate leaf blades with subentire margins ("foliis oblongo-lanceolatis subintegris"). The author cited a synonym from Vahl (1797), "Ch. viride Valh fl. dan. fasc. XX p. 4), explicitly excluding $C$. viride $\mathrm{L}$., and the illustration therein ("T. 1150"). Therefore, the Vahl's illustration is part of the original material for the name $C$. album var. oblongum. We have not been able to trace specimens that are eligible as the lectotype, as all the Chenopodium exsiccata that we found lack collection dates and/or the locality, so the image in Flora Danica appears to be the only extant original material. Fortunately, it matches Visiani's diagnosis, and it can be here designated as the lectotype of the name C. album var. oblongum.

Concerning the application of the name, the plant by Vahl (l.c.) can certainly be ascribed to one of the taxa that are currently recognized under the group of $C$. album, showing some leaves with margins not entire and \pm dentate (leaves with entire leaves are characteristic of $C$. vulvaria L.), and without a median lobe 2-3 longer than the lateral ones (this latter a characteristic of $C$. ficifolium Sm.) (see e.g., Castroviejo 1990, Akeroyd 1993). Within the $C$. album group, the species $C$. opulifolium Schrad. and $C$. strictum Roth s.lat. can be excluded, being characterized by having the leaf blades 3-lobed with length/ width ratio of about 1 (C. opulifolium, see e.g., Pignatti 1982), the blades not lobed, with parallel margins, and stem red with prominent dark-red ribs (C. strictum s.lat., see e.g., Iamonico 2010). The other species belonging to the $C$. album group (C. album L. s.lat., C. probstii Aellen, and C. suecicum Murr.) have many leaves (at least in the middle and lower parts), more or less 3-lobed with margins dentate, excepting for a form of $C$. album s.str., named C. lanceolatum Muhl. ex Willd. that differs in having the proximal and middle cauline leaf blades elliptic to lanceolate, with margins often entire (see e.g., Clemants \& Mosyakin 2003). Willdenow (1809: 291) described $C$. lanceolatum on the basis of a specimen collected by G. H. E. Muhlenberg in "Pensylvania". On the basis of the short diagnosis and description, and the whole circumscription of the other Chenopodium species in Enumeratio plantarum Horti Regii Botanici Berolinensis, it is clear that Willdenow (1809: 288-291) described the new species to distinguish a form with ovato-lanceolate leaves with entire margins and complex inflorescences not arranged in dichotomous cymes (as he indicated for the subsequent listed species, C. aristatum L.). There is one sheet in B (B-W_05365) including three specimens, of which one (B-W_05365-010) bears the annotation "Mublenberg W. [Willdenow]". The specimen born on this sheet (a part 
of the terminal inflorescence) matches Willdenow's diagnosis, and is here designated as the lectotype of the name Chenopodium lanceolatum. According to the current concept and treatments (see e.g., Jonsell 2001, Clemants \& Mosyakin 2003, Iamonico in press), the features showed by C. lanceolatum and C. album var. oblongum completely overlap those of $C$. album subsp. album. Therefore, we here propose to synonymize this latter taxon with $\mathrm{Vi}$ siani's variety (new synonymy).

\section{Conclusions}

The analysis of literature, herbarium investigations and comparison of the protologues allowed us to designate lectotypes for the names Amaranthus hieribuntinus, Atriplex patula var. hastaefolia, and C. album var. oblongum, while the name Amaranthus gangeticus var. cuspidatus is a nomen nudum and thus invalid according to Art. 38.1a of ICN (McNeill et al. 2012). The identities of Amaranthus hierihuntinus, Atriplex patula var. hastifolia, and C. album var. oblongum were also clarified: these names can be considered heterotypic and later synonyms (new synonymies) of, respectively, Amaranthus graecizans subsp. graecizans, Atriplex patula var. patula, and C. album subsp. album. With the aim to understand the concept of $C$. album var. oblongum, C. lanceolatum was also lectotypified and synonymized with Visiani's variety. The accepted names are in bold.

Amaranthus hierichuntinus Vis., Atti Reale Ist. Veneto Sci. Lett. Arti, ser. III, 4: 139 (1858), syn. nov. - Lectotype (designated here): s.l., June-July 1857 , s.coll. s.n. (PADH-0044649!) (Fig. 1).

= Amaranthus graecizans L., Sp. Pl. 2: 990 (1753) subsp. graecizans. - Lectotype (designated by Fernald 1945: 139): Clayton 442 (BM-000051563, image of the lectotype available at http://www.nhm.ac.uk/research-curation/research/projects/linnaean-typification/database/ detailimage.dsml? ID=40700)

Atriplex patula L. var. hastifolia Vis., Fl. Dalm., 1: 237 (1842b), syn. nov. - Lectotype (designated here): [Icon] Tab. VII (Scopoli 1787). Image of the lectotype available at http://bibdigital.rjb.csic.es/ing/Libro. php? Libro=2427\&Pagina $=27$ ).

= Atriplex patula L., Sp. Pl. 2: 1053 (1753) var. patula - Lectotype (designated by Taschereau 1972: 1574): no. 1221.19 (LINN!, image available at http://linneanonline.org/12331/).

Chenopodium album L. var. oblongum Vis., Fl. Dalm., 1: 240 (1842b), syn. nov. - Lectotype (designated here):
[Icon] Tab. 1150 [MLC in original] (Oeder et al. 17611883, Image of the lectotype available at http://bibdigital. rjb.csic.es/ing/Libro.php?Libro=4586\&Pagina=86).

= Chenopodium album L., Sp. Pl. 1: 219 (1753) subsp. album - Lectotype (designated by Brenan in Turrill \& Milne-Redhead 1954: 6: no. 313.8 (LINN!, image available at http://linnean-online.org/3082/).

= Chenopodium lanceolatum Muhl. ex Willd., Enum. Pl.: 291 (1809) - Lectotype (designated here): Pensylvania, G. H. E. Mublenberg s.n. (B-W_05365-010!, Image of the lectotype available at http://herbarium.bgbm.org/ object/BW05365010; see also Ropert 2000+).

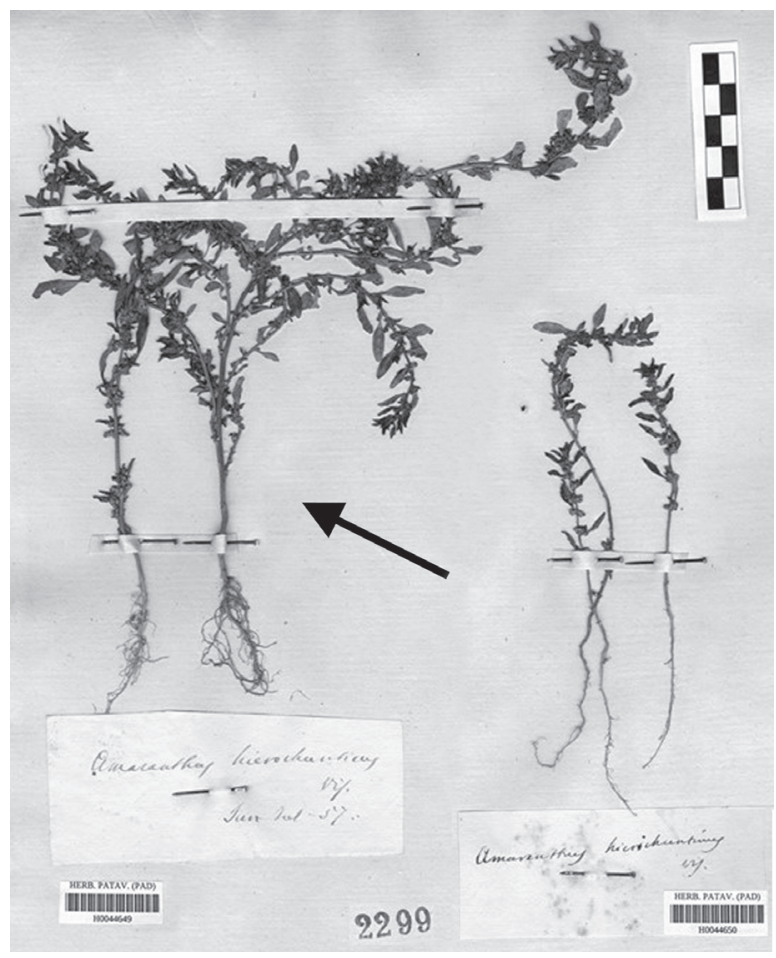

Figure 1: Lectotype of the name Amaranthus hierichuntinus (PAD-H0044649!); arrow indicates the lectotype.

Slika 1: Lektotip imena Amaranthus hierichuntinus (PAD-H0044649!); puščica označuje lektotip.

\section{Acknowledgements}

We are grateful to the Directors and Curators of all quoted Herbaria for their support during the visits of the first author, the loans of specimens/photographs and requests of information. Special thanks to Rossella Marcucci (Herbarium of Padua, Italy) for the permission to reproduce the image of the lectotype of Amaranthus hierichuntinus (no further reproduction or distribution is permitted by any means). 


\section{References}

Akeroyd, J. R. 1993: Atriplex L. In: Tutin, T. G., Burges, N. A., Chater, A. O., Edmondson, J. R., Heywood, V. H., Moore, D. M., Valentine, D. H., Walters, S. M. \& Webb, D. A. (eds.): Flora Europaea (second edition), 1. Cambridge University Press, Cambridge, pp 115-177.

APGIII 2009: An update of the Angiosperm Phylogeny Group classification for the orders and families of flowering plants: APG III. Botanical Journal of Linnaean Society 161: 105-121.

Brenan, J.P.M. 1954: Chenopodium L. In: Turrill W.B. \& MilneRedhead E. (ed.): Flora of Tropical East. Africa, 7. Crow Agent, London, pp 92-95.

Castroviejo, S. 1990: Atriplex L. In: Castroviejo, S., Laínz, M., López Gonzáles, G., Montserrat, P., Muñoz Garmendia, F., Paiva, J. \& Villar, L. (eds.): Flora Iberica, 2. Real Jardin Botanico, Madrid, pp 503-513.

Clemants S.E. \& Mosyakin S.L. 2003: Chenopodium L. In: Flora of North America Editorial Committee (eds.): Flora of North America north of Mexico, 4. Oxford University Press, New York \& Oxford, pp. 275-300.

Clementi, M., Kuzmanović, N., Barina, Z., Lakušić, D. \& Vukojičić, S. 2014: Typification of five names listed by Roberto de Visiani in Plantarum Serbicarum Pemptas. Phytotaxa 170: 57-60. http://dx.doi. org/10.11646/phytotaxa.170.1.9

Clementi, M., Anačkov, G., Miola, A., Vukojičić, S., 2015a: Typification and taxonomical notes on the names published by Roberto de Visiani and Josif Pančić in Plantae Serbicae Rariores aut Novae - Decas II. Phytotaxa (in press)

Clementi, M., Vukojičić, S., Lakušić, D. \& Kuzmanović, N. 2015b: Typification of the names published by Roberto de Visiani and Josif Pančić in Plantae Serbicae Rariores aut Novae-Decas I. Phytotaxa 202(2): 121-134. http://dx.doi.org/10.11646/phytotaxa.202.2.4

Costea, M. 2003: The identity of a Cultivated Amaranthus from Asia and a New Nomenclatural Combination. Econ. Bot. 57(4): 646-649.

Domina, G., Giusso Del Galdo, G., Gargano, D., Labra, M., Peccenini, S., Peruzzi, L. \& Raimondo, F.M. 2012: The Italian Loci Classici Census. Taxon 61(6): 1351-1353.

Fernald, M.L. 1945: Botanical specialities of the Seward Forest and adjacent Areas of Southeastern Virginia. Rhodora 47: 93-142.

Iamonico, D. 2010: Confirmation of the occurrence of Chenopodium strictum subsp. strictum (Amaranthaceae s. 1.) in Italy. Phyton (Horn, Austria) 49(2): 235-240.

Iamonico, D. 20I I: Dysphania anthelmintica (Amaranthaceae), new to the non-native flora of Italy, and taxonomic considerations on the related species. Hacquetia 10(1): 41-48. http://dx.doi.org/10.2478/ v10028-011-0002-x

Iamonico, D. 2012a: (2107) Proposal to reject the name Gomphrena polygonoides (Amaranthaceae). Taxon 61(6): 1326-1327.

Iamonico, D. 2013a: Lectotypification of the Linnaean name Bosea yervamora (Amaranthaceae). Anales Jard. Bot. Madrid 70(2): 187-188. http://dx.doi.org/10.3989/ajbm. 2348

Iamonico, D. 2013b: About the circumscription of Celosia argentea (Amaranthaceae) and the Linnaean related taxa. Phytotaxa 90(1): 61-64. http://dx.doi.org/10.11646/phytotaxa.90.1.1
Iamonico, D. 2014a: Taxonomical, morphological, ecological and chorological notes on Oxybasis chenopodioides and O. rubra (Chenopodiaceae) in Italy. Hacquetia 13(2): 297-302. http://dx.doi. org/10.2478/hacq-2014-0004

Iamonico, D. 2014b: Amarathus gangeticus (Amaranthaceae), a name incertae sedis. Phytotaxa 162(5): 299-300. http://dx.doi. org/10.11646/phytotaxa.162.5.2

Iamonico, D. 2014c: Lectotypification of Linnaean names in the genus Achyranthes L. (Amaranthaceae). Taxon 63(2): 405-407. http:// dx.doi.org/10.12705/632.2

Iamonico, D. 2014d: Lectotypification of Linnaean names in the genus Amaranthus L. (Amaranthaceae). Taxon 63(1): 146-150. http:// dx.doi.org/10.12705/631.34

Iamonico, D. 2015a: Taxonomic revision of the genus Amaranthus (Amaranthaceae) in Italy. Phytotaxa 199(1): 1-84. http://dx.doi. org/10.11646/phytotaxa.199.1.1

Iamonico, D. 2015b: Nomenclature survey of the genus Amaranthus (Amaranthaceae). 3. Names linked to the Italian flora. Pl. Biosystems: in press. http://dx.doi.org/10.1080/11263504.2014.987 188

Iamonico, D. in press: Chenopodium L. In: Pignatti, S. (ed.): Flora d'Italia (nuova edizione). Edagricole, Bologna.

Iamonico, D. \& Das, S. 2014: Amaranthus bengalense (Amaranthaceae) a new species from India, with taxonomical notes on A. blitum aggregate. Phytotaxa 181(5): 293-300. http://dx.doi. org/10.11646/phytotaxa.181.5.4

Iamonico, D. \& Jarvis, C.E. 2012: Lectotypification of two Linnaean names in Chenopodium L. (Amaranthaceae). Taxon 61(3): 864-865.

Iamonico, D. \& Kadereit, G. 2012: Typification of the name Kochia saxicola (Chenopodiaceae). Novon 22(4): 418-421. http://dx.doi. org/10.3417/2011058

Iamonico, D. \& Sánchez Del Pino, I. 2014: Lectotypification of the Linnaean name Gomphrena vermicularis L. (Amaranthaceae). Taxon 63(2): 403-404. http://dx.doi.org/10.12705/632.4

Iamonico, D. \& Sánchez Del Pino, I. 2015: Taxonomic revision of the genus Alternanthera (Amaranthaceae) in Italy. Pl. Biosystems: in press. http://dx.doi.org/10.1080/11263504.2015.1019588

Iamonico, D. \& Somlyay, L. 2014: Typification of Láng's names in Polycnemum (Amaranthaceae s.l.). Phytotaxa 188(2): 118-120. http://dx.doi.org/10.11646/phytotaxa.188.2.6

Iamonico, D. \& Sukhorukov, A.P. 20I4: Studies on the genus Atriplex (Chenopodiaceae) in Italy. VI. Names by Michele Tenore: Atriplex axillaris, A. diffusa, and A. polysperma. Hacquetia 13(2): 285-296. http://dx.doi.org/10.2478/hacq-2014-0005

Jonsell, B.D (ed.). 2001: Flora Nordica - Chenopodiaceae to Fumariaceae, 2. Swedish Royal Academy of Science, Stockolm, 430 pp.

McNeill, J., Barrie, F. R., Buck, W. R., Demoulin, V., Greuter, W., Hawksworth, D. L., Herendeen, P. S., Knapp, S., Marhold, K., Prado, J., Proud'Homme van Reine W. F., Smith, J. F. \& Wiersema, J. H. (eds.) 2012: International Code of Nomenclature for algae, fungi and plants (Melbourne Code). Regnum Vegetabile 154: 1-274. 
Oeder, G.C., Müller, O., Vahl, M., Hornemann, J.W., Schouw, J.F., Vahl, J.L.M., Liebmann, F.M., Steenskrup, J.J.S. \& Lange, J.M.C. 1806: Flora Danica, 22. Aule Regie Typographi N. Mölleri, København, 65 pp.

Peruzzi, L., Domina, G., Bartolucci, F., Galasso, G., Peccenini, S., Raimondo, F.M., Albano, A., Alessandrini, A., Banfi, E., Barberis, G., Bernardo, L., Bovio, M., Brullo, S., Brundu, G., Brunu, A., Camarda, I., Carta, L., Conti, F., Croce, A., Iamonico, D., Iberite, M., Iriti, G., Longo, D., Marsili, S., Medagli, P., Pistarino, A., Salmeri, C., Santangelo, A., Scassellati, E., Selvi, F., Soldano, A., Stinca, A., Villani, M., Wagensommer, R.P. \& Passalacqua, N.G. 2015: An inventory of the names of vascular plants endemic to Italy, their loci classici and types. Phytotaxa 196(1): 1-217. http://dx.doi. org/10.11646/phytotaxa.196.1.1

Pignatti, S. 1982: Flora d'Italia, 1. Edagricole, Bologna, 790 pp.

Röpert, D. (ed.) 2000+ [continuously updated]: Digital specimen images at the Herbarium Berolinense. - Published at http://ww2. bgbm.org/herbarium/ [accessed 15 August 2015].

Sánchez Del Pino, I. \& Iamonico, D. 2015: Jamesbondia, a new Subgenus of Alternanthera (Gomphrenoideae, Amaranthaceae) from Central America and the Caribbean Islands. Pl. Biosystems: in press. http://dx.doi.org/10.1080/11263504.2014.941034

Scopoli, A. 1787: Deliciae florae et faunae Insubricae, 2. Ex Typographia reg. \& Imp. Monasterii S. Salvatoris, Ticinis, 115 pp.

Sukhorukov, A.P. 2006: Zur Systematik und Chorologie der in Russland und benachbarten Staaten (in den Grenzen der ehemaligen UdSSR) vorkommenden Atriplex-Arten (Chenopodiaceae). Annalen des Naturhistorischen Museums in Wien. 108 B: 307-420.
Sukhorukov, A.P. 2014: The carpology of the Chenopodiaceae with reference to the phylogeny, systematics and diagnostics of its representatives. Grif. \& Co., Tula, 400 pp.

Sukhorukov, A.P., Iamonico, D. \& Jarvis, C.E. 2014: The typification of Anabasis foliosa L. (Chenopodiaceae) revisited. Taxon 63(4): 929. http://dx.doi.org/10.12705/634.16

Taschereau, P.M. 1972: Taxonomy and distribution of Atriplex species in Nova Scotia. Canad. J. Bot. 50(7): 1571-1594.

Thiers, B. 2015 [continuously updated]: Index herbariorum, a global directory of public herbaria and associated staff. New York Botanical Garden's Virtual Herbarium. http://sweetgum.nybg.org/ih/ (last accessed 27 March 2015).

Vahl, M. 1797: Flora Danica, 20. Aule Regie Typographi N. Mölleri, København, 65 pp.

Visiani, R. de 1842a: L'orto botanico di Padova nell'anno MDCCCXLII. Tipi di Angelo Sicca, Padova, 151 pp.

Visiani, R. de 1842b: Flora Dalmatica: sive enumeratio stirpium vascularium quas hactenus in Dalmatia lectas et sibi digessit, 1 . Apud Friedericum Hofmeister, Lipsiae, 252 pp.

Visiani, R. de 1858: Recensio Altera Plantarum Minus Cognitarum quas Hortus Patavinus colit. Atti Reale Ist. Veneto Sci. Lett. Arti, ser. III, 4: 133-142.

Willdenow, C.L. von 1790: Historia Amaranthorum. Impensis Ziegleri et Fil., Turici, 38 pp. + 12 Tables. 